\title{
THEORETICAL FUNDAMENTALS OF FORMATION OF INNOVATIVE DEVELOPMENT OF ENTREPRENEURSHIP
}

\author{
Eugeniy Zabashta ${ }^{1}$
}

\begin{abstract}
The article studies and analyses the theoretical fundamentals of the formation of the mechanism of the innovative development of entrepreneurship. Today, the global economy is gradually globalizing. No country in the world can avoid its influence on certain spheres of public life. The process of "globalization" affects the development of innovative entrepreneurship. Today, the driving force of the functioning of innovative entrepreneurship in ensuring economic growth is its development and it is one of the main preconditions for the successful functioning of entrepreneurship in various spheres of the economy, an incentive for increasing the efficiency of production. Innovative entrepreneurship is a special innovative process of creating a new, a kind of management, aimed at finding new ideas and opportunities for the commercial use of innovations. Investment and sufficient funding are required for the development of innovative entrepreneurship. It is investigated that the formation of innovative development of entrepreneurship is constantly based on the search for new methods, the general scheme of formation, and the model of innovative development, is based on innovations, new technologies, which involves expanding the boundaries of innovation activity. Innovative entrepreneurship is a process of creating something new, a management process, based on finding new opportunities, an orientation towards innovation. This is associated with the willingness of the entrepreneur to assume the risk of project implementation or improvement of the existing, as well as economic, financial, moral, and social responsibility. Therefore, innovative entrepreneurship is defined as an economic process that leads to the creation of goods (products, services) and technologies, which are best by their properties, through the practical use of innovations. It is analysed that reformation of the economy is a prerequisite that will lead to increasing competitiveness and provide for the renewal of organizational structures in accordance with the best world trends of innovation activity, taking into account the peculiarities of market transformations in the country, and proposes effective measures to improve the efficiency of innovative entrepreneurship development. The level of development of innovative entrepreneurship determines the country's place in the global space. The low technical level of many sectors of the economy in comparison with industrialized countries (EU, USA) can be overcome only due to the updating of the production base of most enterprises of the country. The development of innovative entrepreneurship in the EU and the USA has become quite successful thanks to individual initiative, creating conditions for the fulfilment of the individual interests of the entrepreneur. Ensuring material wealth, finding appropriate forms of self-expression should represent strong incentives for highly effective work. Therefore, innovative entrepreneurship is considered as the most important tool for the development and transformation of the economic system in terms of modern scientific and technological progress (STP). The use of new types of techniques, management methods, technologies, and organization of production will significantly expand the range, quality, and volume of production, and this will lead to the transformation and reform of the country's economy. The purpose of the study. The main purpose of the paper is to substantiate and deepen the theoretical and methodological provisions regarding the formation of innovative development of entrepreneurship. The object of the study is the processes that form the innovative development of entrepreneurship. The subject-matter of the research is a set of theoretical fundamentals for improving the formation of innovative development of entrepreneurship. Research methods. The theoretical and methodological basis of the study was the modern theories of enterprise management, monographs, publications, and scientific and analytical developments of scientists on the issues of formation of innovative development of entrepreneurship, as well as abstract-logical and graphical methods of research.
\end{abstract}

Key words: innovation, innovative development of entrepreneurship, innovation activity of entrepreneurship, economic reform.

\section{JEL Classification: O31, L26}

Corresponding author:

${ }^{1}$ Kyiv National University of Technologies and Design, Ukraine.

E-mail: ezabashta@i.ua 


\section{Introduction}

The crisis state of the country's economy is characterized by a general decline in the production and product competitiveness, a decrease in interest in innovative entrepreneurship development, and almost a complete absence of a state plan for the development of innovation policy. At the present stage of innovative entrepreneurship, the key role in ensuring economic growth is played by innovative development. As the world practice shows, enterprises, which are able to innovate and apply innovations in the production of new products or services necessary for the consumer, effectively implement the innovation process, gain sustainable competitive advantages, which enables them to successfully develop in the market in an unstable economic environment.

The low technical level of many sectors of the economy in comparison with industrialized countries (EU, USA) can be overcome only due to the updating of the production base of most enterprises of the country. The use of new types of techniques, management methods, technologies, and organization of production will significantly expand the range, quality, and volume of production, and this will lead to the transformation and reform of the country's economy.

Processes of the formation of innovative entrepreneurship in the countries began immediately with the acquisition of independence but its functioning and development are still in crisis. It is also related to unsatisfactory innovation and investment provision, an imperfect tax mechanism, which is the result of an incorrect and unjustified state innovation policy in the field of entrepreneurship.

Today, the main problem of innovation in the event of a change in production technology is the implementation of innovations, their commercialization and promotion on the market, which requires the mandatory modernization of all innovation activities of entrepreneurship. The high level of risk and uncertainty inherent in the innovation activity of entrepreneurship requires continuous monitoring and coordination of innovation changes, as well as the realization of a set of measures for their provision.

Formation of innovative development of entrepreneurship should be oriented towards solving problems, which include the effective use of existing material and technical, raw materials, and labour potential, promotion of programs of fundamental research and development (R\&D), and the implementation of state support for the introduction of innovations.

\section{Formation of innovative development of entrepreneurship}

The term "innovative development of entrepreneurship" is used when research on the mechanism of implementation of scientific and technological progress in the process of activity is carried out and the type of development is discussed and research on the mechanism of implementation of scientific and technological progress in the process of activity, the construction of a state innovation plan, etc., is conducted. The term "innovative development" should be understood as a way of economic growth aimed at the significant improvement of all types of economic activity, first of all, innovation, which is ensured by scientific and technological progress (STP) and provides GDP growth, mainly due to the implementation of science-intensive products and production, services, etc. Innovative entrepreneurship is a key to ensuring competitiveness, therefore, a market participant is interested in using and creating and developing innovation.

Reforming market economy requires incredibly large efforts from enterprises to manage innovative development, so they need support at the appropriate level due to fast-changing conditions. The purpose of the operation of any innovative enterprise is the satisfaction of social needs in certain types of products (works, services) and profit. Examples of enterprises and companies that meet market requirements in the management of innovative development of entrepreneurship are: Volkswagen, Mercedes, BMW, Samsung, Apple, etc. (Butler, 2006).

The implementation of innovation processes in the industrial sector of the economy has been changing in recent years. However, the qualitative characteristic of innovative processes can be submitted through monitoring of innovative development of business entities in the context of the directions presented in Figure 1.

As we see from the monitoring of innovative development of entrepreneurship, the monitoring directions are divided into four main stages:

- the first stage - monitoring of innovation activity of enterprises;

- the second stage - monitoring of the level of costs and financing of innovation activities of enterprises;

- the third stage - monitoring of the number of enterprises that introduced innovations;

- the fourth stage - monitoring of the number of industrial enterprises that implemented innovative products.

\section{Forming the mechanism of innovative development of entrepreneurship}

In order to reform the market economy, it is necessary to analyse the concept of "the formation of a mechanism of innovative development of entrepreneurship." Under the formation of the mechanism of innovative development of entrepreneurship, it is necessary to understand a set of interrelated activities in the study 
THE KEY DIRECTIONS OF MONITORING OF INNOVATIVE DEVELOPMENT OF ENTREPRENEURSHIP

I STAGE. Monitoring of innovation activity of enterprises

- Innovation activity of industrial enterprises by directions of innovations;

Number of industrial enterprises by directions of innovations by types of economic activity.

II STAGE. Monitoring of the level of costs and financing of innovation activity of enterprises

- Distribution of total costs by directions of innovations;

- Distribution of total financing of innovation activity.

III STAGE. Monitoring of the number of enterprises that introduced innovations

- Dynamics of the number of industrial enterprises that introduced innovations;

Number of industrial enterprises that introduced innovations by types of economic activity;

- Number of industrial enterprises that introduced marketing and organizational innovations;

- Number of introduced innovative products at industrial enterprises.

IV STAGE. Monitoring of the number of industrial enterprises that implemented innovative products

- Number of industrial enterprises that implemented innovative products by types of economic activity;

Volume of innovative products sold;

Export sales of innovative products;

- Number of enterprises that purchased and passed new technology (engineering achievements) within and outside of the country by forms of purchase and passage.

Figure 1. Integrated monitoring of innovative development of entrepreneurship

Source: generalized by the author

of stages and general scheme of innovation activity of entrepreneurship, which are based on monitoring of the current state of entrepreneurship and the results of previous innovative changes, on the basis of which it is possible to decide on the choice of directions of innovative development and the formation of appropriate programs and projects (Boichuk, 2016).

The main problems of the development of innovative entrepreneurship are:

- the imperfection of the legislative framework for the development of innovative entrepreneurship;

- lack of significant sources of financing;

- lack of clear and stable state policy in the field of innovation policy;

- levers of stimulation (loans, concessional financing, tax burden, etc.) are not fully used, etc.

The main requirements for building a mechanism of innovative development of entrepreneurship are as follows (Goutam, 2015):

- innovative development of entrepreneurship should be presented in the form of a precise structural scheme (from the definition of the need for innovative development to the calculation of indicators that enable to evaluate the effectiveness of the chosen model); - it is necessary to pay more attention to innovations in all spheres of activity (technical, technological, organizational, managerial, etc.);

- a resource approach should be presented, which can provide the best way for the innovative development of entrepreneurship;

- for the effective construction of innovative development, it is necessary to introduce quantitative indicators that will enable to assess the need of an economic entity for innovative development, as well as the results from the introduction of this mechanism; - innovative development of entrepreneurship should not contradict the mission and corporate purpose;

- the choice of the program of innovative development of entrepreneurship should be based on the economic capacity of a separate economic entity;

- innovative development of entrepreneurship should not contradict the basic requirements and principles laid down on the basis of the regulation (state, regional) of innovation activities of economic entities. 
The main stages of forming the mechanism of innovative development of entrepreneurship are:

- the first stage - the definition of the main goal and purpose of developing the mechanism of innovative entrepreneurship;

- the second stage - the development of principles to achieve the main goal, namely, the formation of a mechanism of innovative development of entrepreneurship, laws that are necessary for the existence of each phenomenon or process in time and space, research of scientific works of scientists, etc.

- the third stage - the study of factors influencing the innovative development of entrepreneurship;

- the fourth stage - the development of indicators and a systematic approach to assessing innovation development of entrepreneurship on the basis of the research of modern approaches in the field of science and innovative technologies;

- the fifth stage - the development of the integral indicator and the methodology for calculating the appropriate scale for identifying alternatives to innovative development of entrepreneurship;

- the sixth stage - the development of measures to eliminate the "imperfect sides" of entrepreneurship and to form reserves for enhancing the capacity for innovative development;

- the seventh stage - the identification of the main tools for the implementation of innovative development of entrepreneurship;

- the eighth stage - analysis and monitoring and evaluation for setting target indicators of the necessary transformations of innovative development of entrepreneurship.

Let's define the main problems that hamper the formation of the mechanism of innovative entrepreneurship:

- firstly, it is an imperfect system of methodological and regulatory support, as well as state support;

- secondly, imperfect legislation and lending to key economic sectors;

- thirdly, the lack of investment and innovation motivations for national and foreign investors.

Today, the main problem of the innovation activity in the event of a change in production technology is the development of knowledge-intensive innovations, their commercialization, and market promotion, which requires the mandatory modernization of all innovation activities of entrepreneurship (Melnyk, 2011).

The high level of risk and uncertainty inherent in the innovation activity of entrepreneurship requires continuous monitoring and coordination of innovation changes, as well as the implementation of a set of measures for their provision.

General scheme of formation of innovative development mechanism for entrepreneurship is represented in Figure 2.

According to the general scheme of forming the mechanism of innovative development of entrepreneurship, we see that the mechanism of formation of innovative entrepreneurship includes: - resource support of innovative development; - factors of the external and internal environment;

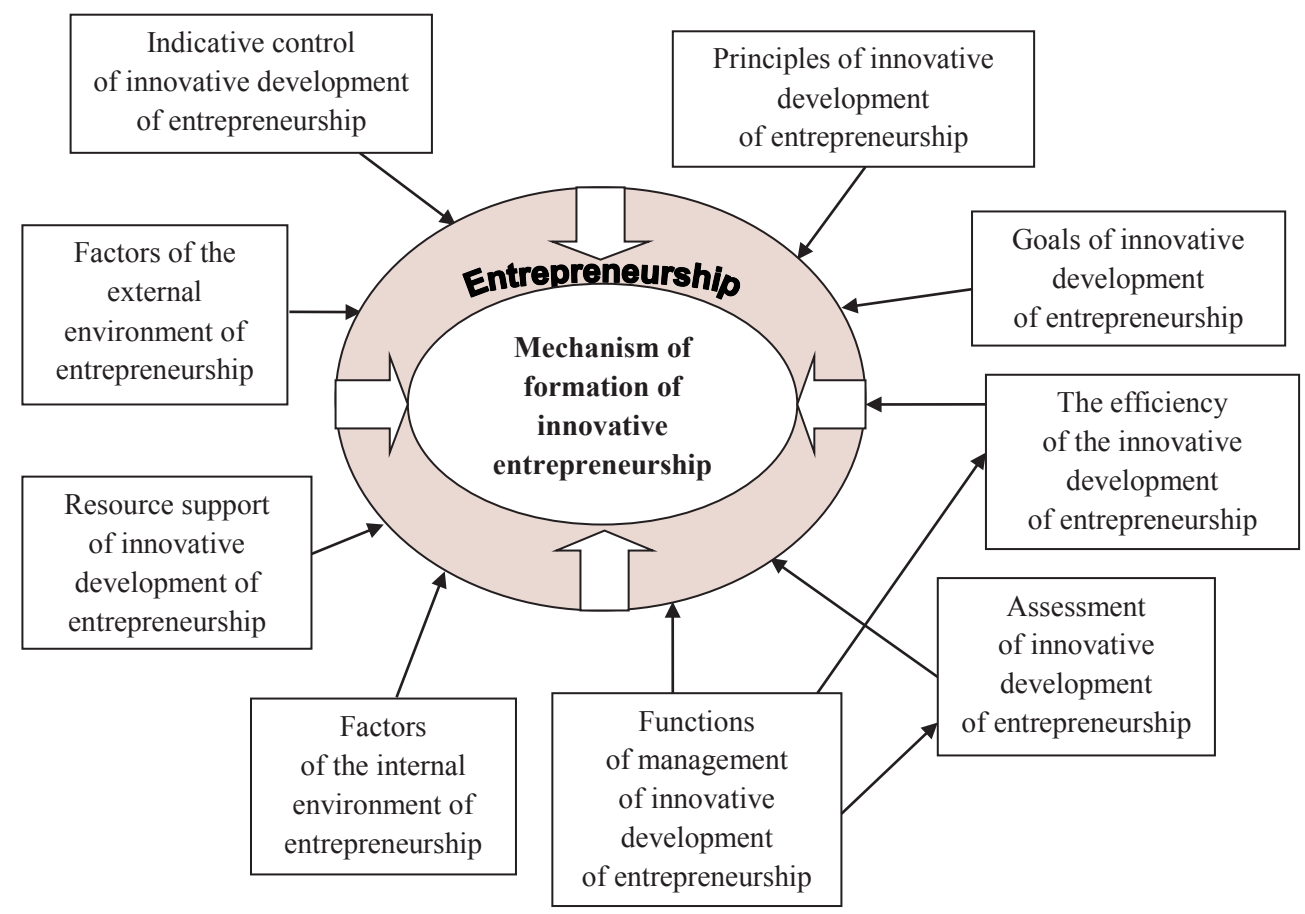

Figure 2. General scheme of formation of innovative development mechanism of entrepreneurship Source: compiled by the author based on (Teece, 2010) 
- principles of innovative development;

- tasks of innovative development;

- the efficiency of innovative development;

- functions of the management of innovative development;

- indicative control of innovative development;

- assessment of innovative development.

\section{Models of innovative development of entrepreneurship}

The transformation and reform of the economy on an innovative basis are a prerequisite for increasing its competitiveness, and also envisage the creation and renewal of organizational and legal structures of governance. The combination of changes that took place in the country's economy led to significant transformations in the organization of economic activity and the emergence of new organizational structures. For this, one needs to investigate and propose own model of innovative development of entrepreneurship.

In order to achieve a positive result, it is necessary for each of the listed elements of the innovation model to be given due attention at all levels of the country's economic development. Today, the following models of innovative development of entrepreneurship can be distinguished (Table 1) (Butnik-Siversky, 2011).

It is investigated that the model of innovative development of entrepreneurship should combine components that are characteristic of different types of models under consideration, starting with state support for the development of innovation policy and ending with the internal motivation of economic entities to the development of innovative entrepreneurship.

Creating an innovative development model will lead to: - decentralization of large and small enterprises in the field of innovation, which can make them more flexible and attractive;

- changes in the management of local authorities, support for enterprises that implement innovation and introduce new technologies, research funding, etc.;
- development of cooperation between entrepreneurs and trade unions in the region, the emergence of a network of small innovative firms (Butenko, 2008).

The need to develop an innovative model of entrepreneurship is stipulated by:

1. Improvement of scientific and technical potential.

2. The need to support a national producer.

3. Creation of an appropriate legislative framework.

4. Attraction of investments and innovations.

5. Strengthening of scientific potential.

6. Formation of a system of state orders for scientific and technological and innovation-technological products.

Today, the main mistake is minimizing the role of the state because it is one of the main investors as the state through investments can affect the enterprise innovative development. The state adopts laws and other enactments and documents by which the regulation of activity of business entities is carried out.

The need for the development of innovative entrepreneurship is specified by the development of innovations, new technologies, and also modern globalization, which stimulates the development of information technology and com+munications (Zjanjko, 2008).

An innovative business model is developed in Figure 3.

By studying the innovative model of entrepreneurship, we can draw the following conclusions:

1) innovative model of entrepreneurship is divided into development factors and deterrents;

2) the process of formation of the innovative model of entrepreneurship depends on the main measures and on development factors and deterrents;

3) the innovative model of entrepreneurship includes: a system of production of scientific knowledge and innovative development, a system of education and advanced training of innovative development, a system of commercialization of innovative development, a system of use of innovative development, a system of management and regulation of innovative development of the economy;

Table 1

Modern models of innovative development of entrepreneurship

\begin{tabular}{|c|c|}
\hline Model of innovative development & Key features \\
\hline Active diffusion of innovations & $\begin{array}{l}\text { Interaction of government with scientific establishments, enterprises, higher education institutions, } \\
\text { and organizations in order to implement innovations. }\end{array}$ \\
\hline State support for innovative forms & $\begin{array}{l}\text { It is aimed at the state support of national innovative structures for promoting the rapid entry } \\
\text { of national products into the world market (EU and US markets). }\end{array}$ \\
\hline Local innovative environment & $\begin{array}{c}\text { Development and establishment of technoparks, technopolises, territorial research and development } \\
\text { centres, clusters, consortia. }\end{array}$ \\
\hline CIS model & $\begin{array}{l}\text { Based on cooperation in science and technology between enterprises and states of CIS in joint } \\
\text { programs, orders, etc. }\end{array}$ \\
\hline $\begin{array}{l}\text { Interbranch scientific and technical } \\
\text { complexes }\end{array}$ & Close to the model of a local innovative environment and covers the same factors. \\
\hline World cooperation & $\begin{array}{l}\text { Includes active participation of the country in the international scientific and technical cooperation, } \\
\text { as well as the broad exchange of scientific results and new technology. }\end{array}$ \\
\hline
\end{tabular}

Source: compiled by the author based on (Uvarova, 2010) 


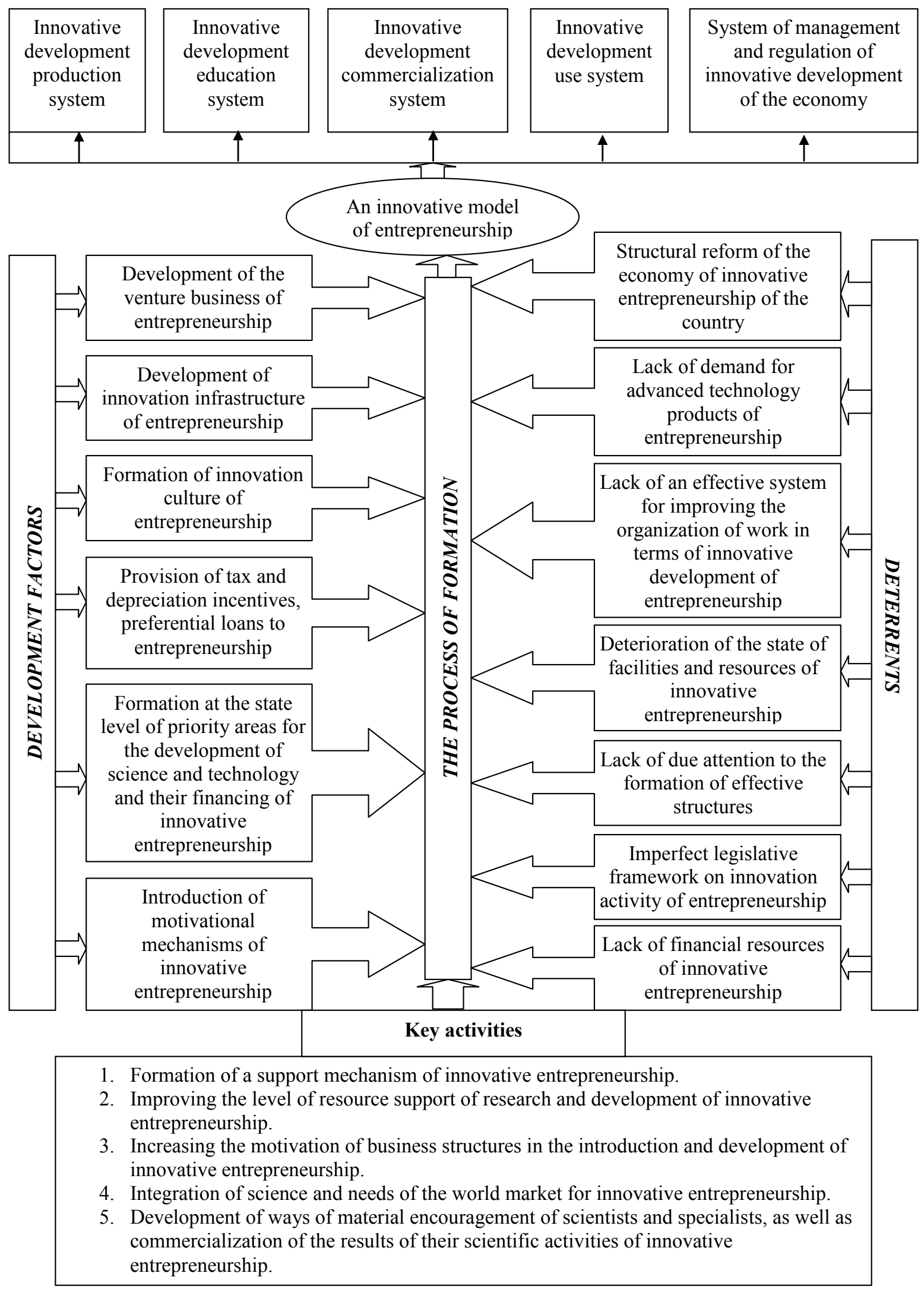

Figure 3. An innovative model of entrepreneurship

Source: generalized by the author 
4) According to the author, measures of the formation of an innovative model of entrepreneurship are:

- firstly, it is a process of forming a mechanism for supporting innovative entrepreneurship;

- secondly, it is a process of developing ways of material encouragement of scientists and specialists, as well as commercialization of the results of their scientific activities of innovative entrepreneurship;

- thirdly, it is a process of increasing the motivation of business structures in the introduction and development of innovative entrepreneurship;

- fourthly, it is a process of integration of science and needs of the world market for innovative entrepreneurship;

- fifthly, it is a process of improving the level of resource support of research and development of innovative entrepreneurship.

5) According to the author, development factors of an innovative model of entrepreneurship include:

- development of the venture business of entrepreneurship;

- development of innovation infrastructure of entrepreneurship;

- formation of innovation culture of entrepreneurship;

- provision of tax and depreciation incentives, preferential loans to entrepreneurship;

- introduction of motivational mechanisms of innovative entrepreneurship;

- formation at the state level of priority areas for the development of science and technology and their financing of innovative entrepreneurship.

6) Deterrents to the development of an innovative model, according to the author, include:

- structural reform of the economy of innovative entrepreneurship of the country;

- lack of demand for advanced technology domestic products of entrepreneurship;

- lack of an effective system for advanced training and improvement of the organization of work of the staff in terms of innovative development of entrepreneurship; - deterioration of the state of facilities and resources of innovative entrepreneurship;
- lack of due attention to the formation of effective structures;

- imperfect legislative framework on innovation activity of entrepreneurship;

- lack of financial resources of innovative entrepreneurship.

\section{Conclusions}

In the context of the crisis situation that has occurred in the country's economy, it is necessary to pay attention to the innovative development of entrepreneurship. The formation of innovative entrepreneurship requires the introduction of innovative technologies and their development. Search should be aimed at generating new ideas, technical solutions, creating innovations. Formation of financial resources of innovative entrepreneurship determines ways to stimulate their interest in introducing innovations. Among them are distinguished: formation of expenses for research and development, the formation of own capital, etc. Formation of innovative development of entrepreneurship should lead to the economic stability of the innovative development of entrepreneurship at the country level.

Consequently, for the formation of innovative entrepreneurship in the country, it is necessary:

- to develop an effective state program for the development of innovative entrepreneurship in the country, taking into account the experience of the leading economies of the world;

- to supplement the legislative framework of laws and regulations with documents and laws that would create conditions for the introduction of modern technologies into the production and further development of venture financing;

- to create an effective legislative framework for the protection of intellectual property rights of scientific and technical products;

- to ensure active participation of enterprises, scientific and technical organizations, and other interested structures in major state programs on innovation development, and initiate the development, approval, and financing of state and local target programs.

\section{References:}

Butenko, A., \& Lazarieva, Y. (2008). Infrastructure components of an innovative economy model. Economics and Forecasting, 4, 69-82. (in Ukrainian)

Bloom, N., \& Reenen, J. V. (2010). Human Resource Management and Productivity, Cambridge: National Bureau of Economic Research.

Butler, D. (2006). Enterprise Planning and Development: Small Business Start-up, Survival and Development. Oxford: Elsevier Ltd.

Boichuk, N. Ya., \& Orel, V. V. (2016). Optymizatsiia upravlinnia biznes-protsesamy na pidpryiemstvakh Ukrainy [Optimization of management of business processes at enterprises of Ukraine]. Zbirnyk naukovykh prats Natsionalnoho tekhnichnoho universytetu Ukrainy «KPI», 17, 173-180. (in Ukrainian)

Entrepreneurship Development for Competitive Small and Medium Enterprises: Report of the Asian Productivity Organization Survey on Entrepreneur Development for Competitive SMEs (2007). Available at: http://www.apo-tokyo.org/00e-books/IS-26_SMEs/IS-26_SMEs.pdf (accessed 10 June 2017). 
Goutam, S., \& Rishiraj, S. (2015). Role of technology in entrepreneurial development: facilitating innovative ventures. International Journal of Emerging Technology and Advanced Engineering, vol. 5, special issue 1, pp. 239-244. Ghoncharova, N. P., Shvydanenko, Gh. O., \& Pavlenko, I. A. (2006). Upravlinnja pidpryjemstvamy - suchasni tendenciji rozvytku: monoghrafija [Enterprise management - contemporary development trends: monograph]. Kyiv: KNEU. (in Ukrainian)

Innovative infrastructure in the context of the national innovation system (economic and legal problems). Ed. by ButnikSiversky, O. (2011). Kyiv: Lazuryt-Polihraf. (in Ukrainian)

Itskovits, H. (2010). Triple spiral: universities - enterprises - state. Innovation in action. Tomsk: Tomsk State University of Control Systems and Radioelectronics. (in Russian)

Innovatsiina Ukraina 2020 : natsionalna dopovid [Innovative Ukraine 2020: national report]. Za zah. red. V. M. Heitsia ta in.; NAN Ukrainy. Kyiv, 2015. (in Ukrainian)

Melnyk, L. H., \& Shkarupa, O. V. (2011). Rol systemnoho upravlinnia innovatsiiamy v klasternykh formuvanniakh [The role of system management of innovation in cluster formations on the basis of an eco-oriented approach]. Marketynh i menedzhment innovatsii, 3, 187-196. (in Ukrainian)

Taiwo, M. A., Ayodeji, A. M., \& Yusuf, B. A. (2012). Impact of small and medium enterprises on economic growth and development. American Journal of Business and Management, 1(1), 18-22.

Teece, D. J. (2010). Business models, business strategy and innovation. Long Range Planning, 43, 172-194.

Uvarova, Iu. M., Hnylobokov, I. O., \& Boiakova, N. V. (2010). Udoskonalennia upravlinnia innovatsiinym protsesom pidpryiemstva [Improvement of the management of the innovation process of the enterprise]. Ekonomika pidpryiemstva, 4, 30-34. (in Ukrainian)

Varvarigos, D., \& Zakaria, I. Z. (2017). Longevity, fertility and economic growth: do environmental factors matter? Review of Development Economics, 21(1), 43-66.

Zjanjko, V. V. (2008). Innovacijne pidpryjemnyctvo: sutnistj, mekhanizmy i formy rozvytku: monoghrafija [Innovative entrepreneurship: the essence, mechanisms and forms of development: monograph]. Kyiv: UNIVERSUM. (in Ukrainian) 